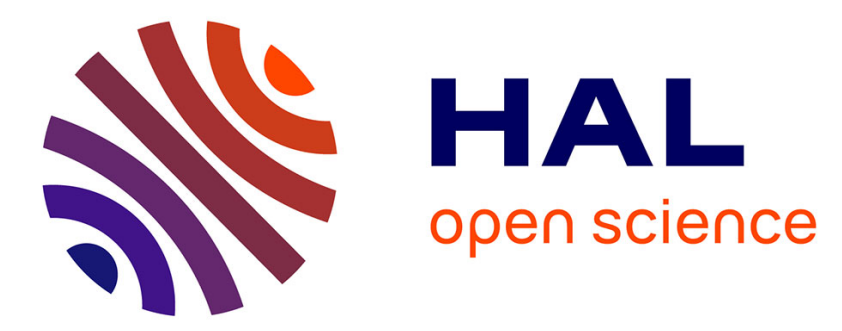

\title{
Experimental climate effect on seasonal variability of polyphenol/phenoloxidase interplay along a narrow fen-bog ecological gradient in Sphagnum fallax
}

Vincent E. J. Jassey, Geneviève Chiapusio, Daniel Gilbert, Alexandre Buttler, Marie-Laure Toussaint, Philippe Binet

\section{To cite this version:}

Vincent E. J. Jassey, Geneviève Chiapusio, Daniel Gilbert, Alexandre Buttler, Marie-Laure Toussaint, et al.. Experimental climate effect on seasonal variability of polyphenol/phenoloxidase interplay along a narrow fen-bog ecological gradient in Sphagnum fallax. Global Change Biology, 2011, 17 (9), pp.2945-2957. 10.1111/j.1365-2486.2011.02437.x . hal-00682513

\section{HAL Id: hal-00682513 https://hal.science/hal-00682513}

Submitted on 26 Mar 2012

HAL is a multi-disciplinary open access archive for the deposit and dissemination of scientific research documents, whether they are published or not. The documents may come from teaching and research institutions in France or abroad, or from public or private research centers.
L'archive ouverte pluridisciplinaire HAL, est destinée au dépôt et à la diffusion de documents scientifiques de niveau recherche, publiés ou non, émanant des établissements d'enseignement et de recherche français ou étrangers, des laboratoires publics ou privés. 
1 Experimental climate effect on seasonal variability of

2 polyphenol/phenoloxidase interplay along a narrow fen-bog ecological

3 gradient in Sphagnum fallax

4 Vincent EJ Jassey ${ }^{1}$, Geneviève Chiapusio ${ }^{1}$, Daniel Gilbert ${ }^{1}$, Alexandre Buttler ${ }^{2,3,4}$, Marie-

5 Laure. Toussaint ${ }^{1}$, Philippe Binet ${ }^{1}$

6

$7{ }^{1}$ Laboratoire Chrono-Environnement, UMR CNRS 6249, UFR Sciences, techniques et

8 gestion de l'industrie, Université de Franche-Comté, F-25211 Montbéliard cedex, France.

$9{ }^{2}$ Laboratoire Chrono-Environnement, UMR CNRS 6249, UFR des Sciences et Techniques,

1016 route de Gray, Université de Franche-Comté, F-25030 Besançon, France.

$11{ }^{3}$ Ecole Polytechnique Fédérale de Lausanne EPFL, Ecological Systems Laboratory ECOS, 12 Station 2, 1015 Lausanne, Switzerland

4 Swiss Federal Research Institute WSL, Site Lausanne, Station 2, 1015 Lausanne, 14 Switzerland

Correspondance to Philippe Binet

Laboratoire de Chrono-Environnement, UMR CNRS 6249, UFR Sciences, techniques et gestion de l'industrie, Université de Franche-Comté, 4 place Tharradin, Montbéliard 25211

Tel: +33 3819946 89; fax: +33 381994661

E-mail address: philippe.binet@univ-fcomte.fr

Running title: phenol/phenoloxidase interplay in peatland

Key words: carbon cycle, climate warming, ecological gradient, open top chambers, peatland, phenoloxidases, polyphenols. 
Extracellular phenoloxidase enzymes play an important role in the stability of soil carbon storage by contributing to the cycling of complex recalcitrant phenolic compounds. Climate warming could affect peatland functioning through an alteration of polyphenol/phenoloxidase interplay, which could lead them to becoming weaker sinks of carbon. Here, we assessed the seasonal variability of total phenolics and phenoloxidases subjected to $2-3^{\circ} \mathrm{C}$ increase in air temperature using Open Top Chambers. The measurements were performed along a narrow fen-bog ecological gradient over one growing season. Climate warming had a weak effect on phenoloxidases, but reduced phenolics in both fen and bog areas. Multivariate analyses revealed a split between the areas and also showed that climate warming exacerbated the seasonal variability of polyphenols, culminating in a destabilization of the carbon cycle. A negative relationship between polyphenols and phenoloxidases was recorded in controls and climate treatments suggesting an inhibitory effect of phenolics on phenoloxidases. Any significant decrease of phenolics through repeatedly elevated temperature would greatly impact the ecosystem functioning and carbon cycle through an alteration of the interaction of polyphenols with microbial communities and the production of extracellular enzymes. Our climate treatments did not have the same impact along the fen-bog gradient and suggested that not all the peatland habitats would respond similarly to climate forcing. 


\section{Introduction}

Boreal peatlands currently represent a terrestrial sink of carbon with approximately one-third of the world's organic carbon (390-455 Pg) (Gorham, 1991; Moore, 2002). The ability of peatlands to store atmospheric carbon resides in the long-term accumulation of partially decomposed organic matter. The accumulated peat is mainly dominated by remnants of mosses of the Sphagnum genus, highly enriched in recalcitrant organochemical compounds such as polyphenols (van Breemen, 1995; Verhoeven \& Toth, 1995). Such compounds play a role both through a polyphenolic network linked to cell walls which could directly preserve Sphagnum-derived organic matter from degradation, and through the release of water soluble phenolics which directly interact with the surrounding environment (van Breemen, 1995; Verhoeven \& Liefveld, 1997). Phenolics produced by Sphagnum have a potential inhibitory effect on fungal and bacterial activity and/or on enzymes involved in organic matter decomposition (Wetzel, 1992; Fenner et al., 2005; Opelt et al., 2007; Mellegard et al., 2009). Among the diversity of enzymatic activities recorded in peat soils, only phenoloxidases mainly produced by fungi - are involved in the polymerization, depolymerisation and transformation of both complex and simple phenolic compounds (Pind et al., 1994; Thormann et al., 2002; Fenner et al., 2005; Baldrian, 2006; Sinsabaugh, 2010). However, acidic conditions, waterlogging and low soil temperatures that occur in peat soils were recognized to limit phenoloxidase activity (Pind et al., 1994, Williams et al., 2000; Freeman et al., 2001a, b; Toberman et al., 2008, 2010). Thus, carbon sequestration in peatlands is thought to partly result from a suppression of phenoloxidase activity (Freeman et al., 2001a, 2004).

The expected increase of air temperatures in boreal regions is predicted to lead to a destabilization of peatland carbon stores (Smith et al., 2004; Strack, 2008). Owing to the temperature regimes that currently constrain biological activities, climate warming may significantly impact the stability of the carbon cycle of peatlands by the breakdown of its 
recalcitrant organic matter and thus act on "the enzymatic latch" (Freeman et al., 2001a, 2004). However, recent research on the effect of climate change on phenoloxidases highlight equivocal results in peatlands (Laiho, 2006; Fenner et al., 2007; Toberman et al., 2008, 2010).

In regions without permafrost the most fundamental distinction among peatland types is between bog and fen (Bridgham et al., 1998, 2001; Rydin \& Jeglum, 2006). Bogs and fens have been found to have different plant communities, hydrology, nutrient availability, and soil chemistry (Bridgahm et al., 1998, 2001; Wheeler \& Proctor, 2000; Rydin \& Jeglum, 2006). Owing to these differences in biotic and abiotic settings, bogs and fens are likely to differ in their response to climate change, (Weltzin et al., 2000, 2001, 2003). Recently, Jassey et al. (2011a) demonstrated that microorganisms (e.g. testate amoebae) and their interplay with polyphenols varied along a short fen-bog gradient. Accordingly, an understanding of how climate change modifies carbon cycling in peatlands by modifying the polyphenol/phenoloxidase interplay in different ecological setting is essential to assess the capacity of peatlands to continue to store carbon.

The aim of this study was to investigate the impact of experimental climate warming on seasonal variation of polyphenols, phenoloxidases and their interplay in different ecological settings. These factors were studied at two depths along the living Sphagnum shoot on a short ecological gradient from a transitional Sphagnum-dominated poor fen to a Sphagnum bog with more pronounced micro-topography. Temperatures were manipulated using open-top chambers placed on half of the sampling plots, and compared with control plots. We hypothesized that (1) seasonal variations of polyphenols, phenoloxidases and their interplay would be different between the structurally more complex Sphagnum "bog" habitat and the more uniform poor fen, and (2) the warming effect would alter the seasonal variations of these factors along the fen-bog gradient. 
Field site and vegetation

The study site is an undisturbed Sphagnum-dominated mire situated in the Jura Mountains (The Forbonnet peatland, France, $46^{\circ} 49^{\prime} 35^{\prime}{ }^{\prime} \mathrm{N}, 6^{\circ} 10^{\prime} 20^{\prime \prime} \mathrm{E}$ ) at an altitude of $840 \mathrm{~m}$ a.s.l. Cold winters (on average $-1.4^{\circ} \mathrm{C}$ ) and mild summers (on average $14.6^{\circ} \mathrm{C}$ ) characterize the site. The annual mean temperature measured at the site over a one-year period from $5^{\text {th }}$ November 2008 to $30^{\text {th }}$ November 2009 was $6.5^{\circ} \mathrm{C}$ and the annual precipitation $1200 \mathrm{~mm}$. carpet across two adjacent areas selected in relation to their wetness, soil micro-topography, vegetation and assessment of sources and decay of organic matter according to Delarue et al., (2011). The first sampling area (called "fen") was a transitional Sphagnum-dominated poor fen with a relatively flat and homogeneous topography, characterized by a moss cover dominated by $S$. fallax and by the lack of $S$. magellanicum. Vascular plants such as Eriophorum vaginatum, Vaccinum oxycoccus and Andromeda polifolia were recorded in very low abundance. Scheuchzeria palustris and Carex limosa occurred outside of the studied plots. The second sampling area (called "bog") was a Sphagnum bog directly adjacent to the fen area. Patterns of hummocks with S. magellanicum, V. oxycoccos, E. vaginatum and Calluna vulgaris, and hollows with lawns of S. fallax, Carex rostrata and A. polifolia characterized the sampling area. The terms "fen" and "bog" are used for simplicity and to denote the existence of a trophic and wetness gradient inferred from the vegetation.

117 Environmental manipulations and data collection

In each of the two sampling areas, six plots were selected in representative surfaces. Among the 12 sampling plots, the maximal distance between the two most distant plots was 
ca. $30 \mathrm{~m}$. In both sampling areas, 3 plots (replicates) were randomly assigned as controls and 3 plots were assigned as climate warming treatment (begin April, 2008). An increase of air and soil temperatures was passively achieved by placing hexagonal ITEX open-top chambers (hereafter "OTC") over the vegetation (Marion et al., 1997). Since warming in OTC chambers also affects the top-soil humidity, we hereafter name this treatment "climate effect". Hexagonal OTCs were $50 \mathrm{~cm}$ high, had a diameter of $1.8 \mathrm{~m}$ at the top and $2.5 \mathrm{~m}$ at the bottom, and were made of transparent polycarbonate. To reduce edge effects such as reduced precipitation in the chamber we used the OTC design described by Aerts et al. (2004) and Dorrepaal et al. (2004). In each plot, air temperature (10 $\mathrm{cm}$ above the Sphagnum surface) and soil temperature (7 $\mathrm{cm}$ below the Sphagnum surface) were recorded continuously every 30 minutes using thermocouple probes and a datalogger (CR-1000 Campbell). Moreover, in each plot, $\mathrm{pH}$, conductivity, water content of Sphagnum and the depth to the water table (DWT) were measured at each sampling campaign.

Every month from $25^{\text {th }}$ May 2009 to $25^{\text {th }}$ November 2009, samples of S. fallax were collected in each plot for the study of phenolic compounds, fungi-producing phenoloxidases and phenoloxidase activities around 10 permanent markers inserted in moss carpets. The goals of this sampling design were (1) to allow for multiple sampling at the site over time, and (2) to obtain a composite sample from each plot and avoid any bias due to spatial heterogeneity. S. fallax shoots were cut into two pieces (sampling depth): 0-3 cm (living "top segments") and 3-10 cm (early declining "bottom segments") from the capitulum.

Phenolic compounds quantification

Primarily bound (hereafter "bound phenolics") and water-soluble phenolic (hereafter "free phenolics") compounds were extracted from lyophilized mosses as described in Jassey et al. (2011a). Briefly, bound phenolic compounds were extracted using ethanol / distilled water 
solution $(80 / 20 \mathrm{v} / \mathrm{v})$ and free phenolics using distilled water. Free and bound total phenolic contents were quantified with the Folin-Ciocalteau reagent and were expressed in $\mathrm{mg}$ equivalent gallic acid $\left(A_{760}\right)$ per gram of Sphagnum dry mass $\left(\mathrm{mg} \mathrm{g}^{-1} \mathrm{DM}\right)$.

\section{Quantification of culturable fungi-producing phenoloxidases}

Culturable fungi-producing phenoloxidases were counted as described by Criquet et al. (2000). Two grams fresh weight of Sphagnum was powdered $\left(<0.5 \mathrm{~mm} ; \mathrm{SEB}^{\circledR}\right.$ Optimo compact mixer) and suspended in $250 \mathrm{~mL}$ of a $0.85 \% \mathrm{NaCl}$ solution with $0.05 \%$ Tween 80 . This mixture was agitated for $2 \mathrm{~h}$ on a reciprocal shaker $(120 \mathrm{rpm})$. The extract was diluted $\left(10^{-1}\right.$ to $\left.10^{-3}\right)$ in $\mathrm{NaCl}(0.85 \%)$ solution and $0.1 \mathrm{~mL}$ of each dilution was used to inoculate a medium containing $5 \mathrm{~g}$ of malt (Sigma), $15 \mathrm{~g}$ of agar (Sigma), $50 \mathrm{mg}$ of chloramphenicol (Sigma) and $0.5 \mathrm{~mL}$ of guaiacol (Sigma) per liter. The fungi-producing phenoloxidases were revealed by the red color of the environment related to the oxidation of guaiacol. Results are expressed in colony forming units per gram of Sphagnum dry mass (CFU g $\left.{ }^{-1} \mathrm{DM}\right)$.

\section{Phenoloxidase activities quantification}

Phenoloxidase activities were quantified following the method described by Criquet $e t$ al. (1999). Phenoloxidases were extracted by adding in a Pyrex bottle $3 \mathrm{~g}$ of fresh weight of powdered Sphagnum with $50 \mathrm{~mL}$ of a $0.1 \mathrm{M} \mathrm{CaCl}_{2}$ solution with $0.05 \%$ Tween 80 and $20 \mathrm{~g}$ of polyvinylpolypyrrolidone. The samples were shacked at room temperature for $1 \mathrm{~h}$ on a reciprocal shaker $(120 \mathrm{rpm})$. The suspension of each extract was filtered through a double layer of gauze to remove floating debris and centrifuged at $10000 \mathrm{~g}$ for $10 \mathrm{~min}$ at $4^{\circ} \mathrm{C}$. Then the supernatant was filtrated through 1.2 $\mu \mathrm{m}$ Whatman GF / D filters and concentrated for $24 \mathrm{~h}$ in a cellulose-dialysis tube (Medicell Internationel Ltd.) with a $10 \mathrm{kDa}$ molecular mass cutoff, covered with polyethylene glycol (PEG, Sigma-Aldrich), until a final volume of 1/10 of the initial volume. Enzymatic activities were measured using a 96 well microtiter plate with 
L-DOPA $(10 \mathrm{mM})$. For each sample, 8 pseudo-replicate wells were included. Assay wells received $150 \mu \mathrm{l}$ of extract. Phenoloxidase activities were measured by adding $100 \mu \mathrm{L}$ of LDOPA. For each sample, 8 pseudo-replicate wells containing $150 \mu \mathrm{l}$ of boiled extract ( $2 \mathrm{~h}$ at $90^{\circ} \mathrm{C}$ ) were performed as control. Then samples were incubated at $23^{\circ} \mathrm{C}$ and L-DOPA oxidation rates were monitored spectrophotometrically at $460 \mathrm{~nm}$ for $24 \mathrm{~h}$ using a microstation plate reader (Bioadvance).

Enzymatic activities were calculated by subtracting the mean absorbance of control wells from the mean absorbance of extract wells and by using Beers Law. The molar absorbancy coefficient for the L-DOPA product 3-dihydroindole-5,6-quinone-2-carboxylate (dicq) (3.7 x 10 $0^{4} \mathrm{M}^{-1} . \mathrm{cm}^{-1}$; Mason, 1948) was used and activities were expressed in enzymatic units (U) defined as one nmol of substrate oxidized per $\mathrm{h}^{-1}$ per $\mathrm{g}$ of dry $\mathrm{m}$ ass.

\section{Numerical analysis}

To compare the general effects of the OTCs on environmental parameters during the 7 months of our study, daily average temperature, as well as minimum and maximum daily temperatures, $\mathrm{pH}$ and conductivity were calculated for spring (May-June), summer (late-JuneSeptember) and autumn (late-September-November). Then repeated measures ANOVA were computed among sampling areas to focus on the effect of OTCs on these factors with time as repeated measure (time $=3$ : spring, summer and autumn). The depth and climatic effect on phenolic compounds (free and bound), culturable fungi-producing phenoloxidases and phenoloxidase activities were also analysed using repeated measures ANOVA with time as repeated measure (time $=7$ : May-November). Each dataset was thereafter split by month to get one response matrix per month for each biological factor using one-way ANOVA. In parallel, correlations between free phenolics, fungi-producing phenoloxidases and phenoloxidase activity in controls and OTCs were determined along the fen-bog gradient 
using general linear models (GLM) and one-way ANOVAs. The residuals from ANOVAs were tested for normality. Moreover, the coefficient of determination of each variable in the models (adjusted $R^{2}$ ) was determined with an analysis of variance.

Redundancy analyses (RDA) were applied to Sphagnum related biochemical variables (polyphenols, phenoloxidases, culturable fungi-producing phenoloxidases) for each Sphagnum segment among the fen and the bog areas using climatic treatment (a binary variable with two levels: Control and OTC), Sphagnum moisture content and time (months coded as classes) as explanatory variables. The interactions between climatic treatment and Sphagnum moisture content were also included in the model. The significance of the model and of each explanatory variable included in the model was tested using 1,000 permutations (Gillet et al., 2010). Partial RDAs were also computed after removing the time effect (months) from the ordination following the same method. Additionally, variation partitioning using RDA and adjusted $R^{2}$ was applied to compare the respective effect of each explanatory variable alone (Peres-Neto et al. 2006).

Multiple factor analysis (MFA) was used to symmetrically link seven groups of descriptors split in seven sub-matrices: the two Sphagnum related biochemical matrices (phenolic compounds and phenoloxidase data sets), the two abiotic data sets describing physical (depth to water table, air and soil temperature, rainfall and Sphagnum moisture content) and chemical (conductivity and $\mathrm{pH}$ ) environmental conditions, the climatic data set describing climate treatment (a binary variable with two levels: OTC coded with 1 and control with 0), and the two data sets describing the seasons (spring, summer or autumn coded as classes), and the sampling areas (fen or bog coded as classes). MFA was chosen because it allows the simultaneous coupling of several groups or subsets of variables defined on the same objects and to assess the general structure of the data (Escofier \& Pagès, 1994). Briefly, MFA is basically a PCA applied to the whole set of variables in which each subset is 
weighted, which balances inertia between the different groups and thus balances their influences. RV-coefficients (Pearson correlation coefficient, ranging from 0 to 1 ) were used to measure the similarities between two data matrices and were tested by permutations (Robert \& Escoufier, 1976; Josse et al., 2008). Euclidean distances of global PCA were used in MFA to perform cluster analysis according to the Ward method, and the resulting dendrogram was projected in the MFA ordination space. This allows discovering the main discontinuities among groups and/or sites described by all biotic and abiotic subsets of variables (Carlson et al., 2010; Borcard et al., 2011).

All multivariate analyses were performed with the software R 2.10.1 (R Development Core Team 2010) using the vegan (Oksanen et al., 2010) and FactoMineR (Husson et al., 2009) packages.

\section{Results}

Seasonal variation of climate variables

In spring and summer (May to September), the OTCs significantly increased the daily maximum air temperature (an average of $3^{\circ} \mathrm{C}$; ANOVA $P<0.01$ ) and the average air temperature (an average of $1^{\circ} \mathrm{C}$; ANOVA $P<0.01$ ). Climate treatment also significantly affected the daily soil temperature in spring in the bog area (an average increase of $0.6^{\circ} \mathrm{C}$; ANOVA $P<0.05$ ) and in summer in the fen area (an average increase of $0.8^{\circ} \mathrm{C}$; ANOVA $P<$ 0.05). No significant differences emerged for the minimum and maximum soil temperatures. In autumn, no significant effect of OTCs was recorded along the gradient for air and soil temperature. An indirect effect of climate treatment was also observed in Sphagnum mosses, since a significant decrease of Sphagnum water content in OTCs was recorded in summer 
(August and September) in both Sphagnum segments in the bog area, and in top segments in the fen area (ANOVA $P<0.05$. Fig. 1).

Rainfall significantly varied following the seasons with a decrease from June (156 $\mathrm{mm}$ ) to August, September and October (a monthly average of $72 \mathrm{~mm}$ ) and an increase in November $(231 \mathrm{~mm})$. These variations were also reflected in the depth to water table. Following the seasons and climate treatments, average monthly $\mathrm{pH}$ did not significantly vary in both sampling areas (Table 1). Conversely, the conductivity increased from spring to autumn in both sampling areas, with significant differences between controls and OTCs in summer (bog area, $P=0.05$ ) and in autumn (fen area, $P=0.01$ ).

\section{Climate effect on phenolic compounds and seasonal variations}

Regardless of seasonal variations, climate effect and fen-bog gradient, bound and free phenolic contents were significantly higher (ANOVA $P<0.001)$ in top segments as compared to bottom segments (Fig. 2), except bound phenolics in the bog area $(P=0.16)$. The two phenolics variables were also positively correlated, with respectively $r=0.38$ and 0.37 in the bog area (ANOVA, $P<0.01$ ) and $\mathrm{r}=0.70$ and 0.41 in the fen area (ANOVA, $P<0.001$ ). The climate effect on bound phenolics resulted in a decrease of concentration of an average of 0.4 $\mathrm{mg} \mathrm{g}^{-1} \mathrm{DM}$ in the two sampling areas, particularly in spring and summer in top segments $(P=$ 0.04 and 0.02 , respectively). The climate effect on free phenolics was essentially recorded in the fen area for both Sphagnum segments, with constantly lower concentrations in OTCs than in controls over the seasons (ANOVA, $P=0.001$ ) (Fig. 2), whereas the climate effect in the bog area was more rare.

In controls, seasonal variations of bound phenolics were recorded in top segments along the fen-bog gradient ( $P=0.04$ and 0.05 , respectively) (Fig. 2a, b, c, d), especially from May to August with a significant decrease of an average of $1.5 \mathrm{mg} \cdot \mathrm{g}^{-1} \mathrm{DM}$. In bottom 
segments of controls, no significant seasonal variations of bound phenolics were recorded along the fen-bog gradient ( $P=0.86$ and 0.66 , respectively), with an average of respectively $1.5 \mathrm{mg} \mathrm{g}^{-1} \mathrm{DM}$ in the bog area and $1.0 \mathrm{mg} \mathrm{g}^{-1} \mathrm{DM}$ in the fen area. As for bound phenolics, seasonal variations of free phenolics in controls were recorded in top segments with a significant decrease in summer (from 1.4 to $0.8 \mathrm{mg} \mathrm{g}^{-1} \mathrm{DM}$ in the two sampling areas; $P<$ 0.01 and 0.03 , respectively). In bottom segments, no seasonal variations of free phenolics were recorded, with an average of $0.8 \mathrm{mg} \mathrm{g}^{-1} \mathrm{DM}$ along the fen-bog gradient (Fig. 2e, f, g, h). In addition, a significant correlation was found between the decrease of phenolics (free and bound) and the decrease of Sphagnum moisture content in summer (ANOVA, $P<0.01$ ) in both segments in the bog area, and in top segments in the fen area.

In OTCs, the same seasonal variations as in controls were recorded in Sphagnum segments and for both phenolics along the fen-bog gradient $(P<0.05$ for all) (Fig. 2). As for controls, the same significant correlations were recorded between the decrease of phenolics (free and bound) and the decrease of Sphagnum moisture content in summer (ANOVA, $P<$ $0.05)$.

Climate effect on culturable fungi-producing phenoloxidases and enzymatic activity, and seasonal variations

Significant differences between top and bottom segments of Sphagnum were recorded with overall higher densities of fungi-producing phenoloxidases and higher phenoloxidase activities in bottom segments as compared to top segments in both sampling areas (ANOVA $P<0.05)$

For densities of culturable fungi-producing phenoloxidases, the climate effect was only significant in the fen area in top segments (ANOVA $P=0.03$ ), with a significant lower value in June in OTCs compared to control (Fig. 3a, b). Seasonal variations were recorded for 
both Sphagnum segments in the fen and bog area, with a peak in June in controls $(P<0.05)$ (Fig. 3 a, b, c, d), while in OTCs this peak was only recorded in the bog area (Fig. 3c, d). Climate effects on phenoloxidase activity demonstrated equivocal results in the fen area, while phenoloxidase activity tended to be higher in OTCs in the bog area (Fig. 3e, g).

Significant positive correlations were also found between densities of fungi-producing phenoloxidases and extracellular phenoloxidase activities, in both sampling areas and both climate treatments (on average $\mathrm{r}=0.40$; ANOVA, $P<0.05$ ). In parallel, significant negative correlations between free phenolic compounds and phenoloxidase activities were found for controls in the fen and bog areas when top and bottom Sphagnum segments were pooled (Fig. 4a, b). The same tendency was recorded in OTCs, except in the bog area (Fig. 4b). Additionally, the combination of fungi and free phenols in a general linear model explained respectively $27.4 \%$ and $10.6 \%$ of the variability of phenoloxidase activity in controls, and $29.6 \%$ and $0.6 \%$ in OTCs in the bog area (adjusted $R^{2} ; P<0.001$ ). For the fen area another patterns occurred since fungi and free phenolics explained respectively $13.7 \%$ and $9.8 \%$ of the variability of phenoloxidase activity in controls, and $11.3 \%$ and $25.8 \%$ in OTCs (adjusted $R^{2}$; $P<0.001)$.

The phenol-phenoloxidase complex and its relation to abiotic variables

The contribution of the explanatory variables in the RDA (Table. 2) showed that time (months) has a major influence on the moss biochemical patterns. In bottom segments sampling time explained between $41 \%$ and $66 \%$ of the variation. In top moss segments, biplots of partial RDAs showed that Sphagnum related biochemical variables were influenced by climate treatment, as shown by the separation of control and OTC plots along the first RDA axis (Fig. 5a, c). Together, OTCs and Sphagnum moisture content explained 20.6\% (fen) and $27.1 \%$ (bog) of the variation of biochemical factors $(P<0.05)$ in top segments. 
Variation partitioning and adjusted $R^{2}$ showed that OTCs alone explained a higher variation in the fen area than in the bog area, whereas Sphagnum moisture content has higher influence in the bog than in the fen (Table 2). On the other hand, the biochemical descriptors showed a strong opposition between phenolics and warming treatment (OTC) in all biplots, while fungi appears linked to Sphagnum moisture content, particularly in top segments.

If we consider all samples together along the fen-bog gradient in the multiple factor analysis (Fig. 6), a clear pattern appeared, with a split into the three seasons (spring, summer and autumn) and within each partition a subdivision into fen and bog areas, each of these subdivisions being further divided into OTC and control plots. The RV-coefficients (Table 3) indicate strongest links between Sphagnum related biochemical variables, sampling area, climate warming and seasons, and between sampling area and physicochemical environment.

\section{Discussion}

Polyphenol/phenoloxidase interplay in Sphagnum mosses and along the fen-bog gradient

Sphagnum related biochemical factors quantified in this work yielded different results according to Sphagnum segments. Total phenolic content (free and bound) was higher in living top segments as compared to decaying bottom segments in both sampling areas. Such differences have been also observed in S. fallax under controlled conditions (Jassey et al., 2011b). This phenomenon is explained by a higher phenolic metabolism in capitulum than in lower part of the shoot, since Sphagnum capitula (top segments) constitute the living part of the moss where most of the metabolic processes occur, including the growth (Clymo \& Hayward, 1982). The reduction of phenolics towards the lower part of the shoot was also accompanied by an increase of culturable fungi-producing phenoloxidases and of phenoloxidase activity, suggesting a higher degradation of recalcitrant phenolics in early 
declining Sphagnum segments (Baldrian, 2006; Toberman et al., 2010; Sinsabaugh \& Follstad Shah, 2011). These results also pointed to the fact that at low concentrations free phenols may induce phenoloxidase activity, and inhibit the oxidation activity at high concentration (Sinsabaugh, 2010). Given that no clear correlation was found between fungi and free phenols, such vertical gradient also highlighted a possible direct inhibitory effect of free phenols on phenoloxidase activity (Wetzel, 1992; Freeman et al., 2001a; Fenner et al., 2005).

Our results likewise demonstrated a strong relationship between fungi and phenoloxidase activities. Phenoloxidase activity is essentially attributable to lignolytic fungi such as basidiomycetes (Criquet et al., 2000; Thormann et al., 2002; Baldrian, 2006). Fungal activity is known to be directly influenced by the supply of organic matter (Berg et al., 1998; Criquet et al., 2000). A study in the same experimental site demonstrated over the fen-bog gradient an increase of organic matter content in the upper $10 \mathrm{~cm}$ soil layer, which induced higher fungal activity (Delarue et al., 2011). Thus, all of these findings emphasize that phenoloxidase activity was mainly controlled by fungi and secondarily by phenols.

Beside the differences between Sphagnum segments, different patterns of polyphenol content and phenoloxidase activities were recorded along the fen-bog gradient over the seasons. In particular, phenoloxidase activities were more intense in the bog area than in the fen area. Again, this result appeared linked to fungi. The abundance of vascular plants is higher in the bog area and supplies more easily decomposable organic matter, favouring fungal activity (Delarue et al., 2011). A number of studies have demonstrated that fen and bog litters were characterized by distinct patterns of microfungal community, especially in the surface horizons (Thormann et al., 2001, 2002, 2004; Thormann, 2006; Artz et al., 2007). Thus, vegetation patchiness along the fen-bog gradient may directly affect fungal community composition, and indirectly phenoloxidase activity. In particular, the quality and quantity of plant-derived labile carbon resulting from vegetation succession may directly influence fungal 
diversity, e.g. polymer- and recalcitrant polymer degraders (Thormann, 2006). On the other hand, the influence of free phenols on phenoloxidases was higher in the fen area than in the bog and this could be explained by qualitative differences of phenolics in Sphagnum along the gradient (Opelt et al., 2007). When comparing phenolic content in Sphagnum from different ecological setting, Folin assay only gives a global tendency of phenolic variation, and not the quality of free phenols that may influence phenoloxidase activity. Such results clearly call for a detailed analysis of phenolic variation (e.g. phenolic acids or flavonoids).

Climate effect on polyphenols, phenoloxidases and their interactions along the fen-bog gradient

As described in previous studies (Dorrepaal et al., 2004; Aerts, 2006), higher air temperatures induced higher evapotranspiration, which resulted in lower Sphagnum moisture content during summertime. Obviously, higher evapotranspiration also could have sometimes induced lower soil temperature by heat loss towards atmosphere and reduction of soil thermal conductivity, thus explaining the so-called marginal effect of OTCs on soil temperature (Dabros et al., 2010). Despite contrasted effects of OTCs on air and soil temperature, a climate effect has been recorded on biochemical variables measured along Sphagnum segments.

Seasonal effects were predominant for the biochemical variation in Sphagnum carpet. However, multivariate analyses revealed a climate warming effect beyond the seasonal variations of Sphagnum biochemical related factors. As observed elsewhere (Aerts, 2006; Bragazza, 2008; Dabros and Fyles, 2010; Dabros et al., 2010), the increase of air temperature associated with the reduction in rainfall led to heat waves, and the impact of these events was exacerbated in OTCs increasing drought in top-soil. Enhanced top-soil aeration as a result of water table drawdown and air temperature increase was recognized to influence 
phenoloxidase activity and polyphenols (Freeman et al., 1993, 2001a, b; Toberman et al., 2008; Ellis et al., 2009). As supported by current findings in peatlands (Pind et al., 1994; Williams et al., 2000; Freeman et al., 2001a; Toberman et al., 2008, 2010; Sinsabaugh, 2010), peat soil environmental factors (i.e. acidic $\mathrm{pH}$, water table depth, and oxygen) mainly inhibit phenoloxidase activity, explaining our weak variations of phenoloxidases with climate warming.

In parallel, climate warming had greatest impact on the phenolic metabolism with a decrease of phenolics related to the decrease of Sphagnum moisture in OTCs and the increase of air temperatures. The level of total phenolic compounds tends to be lower in several boreal species under elevated temperatures (Veteli et al., 2007). Such decrease may be explained by a diminution of carbon partitioning to phenolics (Herms \& Mattson, 1992; Mattson et al., 2005). Elevated temperatures are recognized to induce better growth of Sphagnum species (Breeuwer et al., 2008). It might well be that a trade-off between growth and differentiation (i.e. the production of carbon-based secondary metabolites such as phenols) occurred, with a potential diminution of carbon skeletons allocation to phenolics (Mattson et al., 2005; Veteli et al., 2007). Such results imply that any repeated significant decrease of phenolics through more intense and frequent heat waves - as predicted by climate scenarios (Meehl \& Tabaldi, 2004; Schär et al., 2004; IPCC, 2007) - will probably lead to the opening of the enzymatic latch, as described by Freeman et al. (2001b).

Furthermore, our climate experiment demonstrated that climate warming has not had the same impact along the fen-bog gradient since a stronger decrease of polyphenols was recorded in the fen area. This decrease induced a switch between fungi and free phenols, leading to a reduction of the potential inhibitory effect of free phenols on phenoloxidases. However, the decrease in the density of culturable fungi-producing phenoloxidase during dryer periods could not compensate for the decrease of phenolics and lowering of their 
inhibitory effect on phenoloxidase activity. Alternatively, or additionally, phenolics may also have inhibitory effects on other microbial activities with implication for the carbon cycle, such as hydrolase activity (Fenner et al., 2005, 2007). Thus, the reduction of the inhibitory effect of free phenols could affect carbon cycling in the fen area through another microbial/polyphenols interplay (e.g. Jassey et al., 2011a). In the bog area phenoloxidase activity remained the key factor influenced by climate treatment with a slight increase of activity in top segments, leading to potentially higher degradation of recalcitrant materials in surface horizons. In contrast to the fen area, it appeared that fungi mainly influenced phenoloxidases in OTCs, as shown by GLMs.

Although a slight increase of temperature induced by OTCs is not strong enough to significantly affect the decomposition rate of Sphagnum litter on short-time scale (Dabros et al., 2010), our results demonstrated that already within a 7-month period key elements of the carbon cycle can be altered in surface horizons. Furthermore, our climate experiment highlights different responses of Sphagnum related biochemical variables along the fen-bog gradient. The main consequence is that not all the peatland habitats would respond similarly to climate forcing. Ultimately, our results suggest a destabilization of peatland ecosystems and reinforce the point that phenoloxidase/polyphenol interplay is especially critical to understanding the response of peatlands to climate change.

\section{Acknowledgments}

This research is a contribution of the ANR PEATWARM project (Effect of moderate warming on the functioning of Sphagnum peatlands and their function as a carbon sink).

PEATWARM is supported by the French National Agency for Research under the “Vulnerability: Environment —Climate" Program (ANR-07-VUL-010). Further funding to V. Jassey by the Franche-Comte Region is kindly acknowledged. The authors would like to 
thank F. Gillet (Université de Franche-Comté, France) for his statistical assistance. They also thank R. Payne (University of Manchester, England) for his English edits, and the three reviewers for their valuable review of this work.

\section{References}

Aerts R (2006) The freezer defrosting: global warming and litter decomposition rates in cold biomes. Journal of Ecology 94(4): 713-724.

Aerts R, Cornelissen JHC, Dorrepaal E, van Logtestijn RSP, Callaghan TV (2004) Effects of experimentally imposed climate scenarios on flowering phenology and flower production of subarctic bog species. Global Change Biology 10(9): 1599-1609.

Artz REE, Anderson IC, Chapman SJ, Hagn A, Schloter M, Potts JM, Campbell CD (2007) Changes in fungal community composition in response to vegetational succession during the natural regeneration of cutover peatlands. Microbial Ecology 54(3): 508:522.

Baldrian P (2006) Fungal laccases - occurrence and properties. Fems Microbiology Reviews 30(2): 215-242.

Berg MP, Kniese JP, Verhoef HA (1998) Dynamics and stratification of bacteria and fungi in the organic layers of a Scots pine forest soil. Biology and Fertility of Soils 26(4): 313322.

Borcard D, Gillet F, Legendre P (2011) Numerical Ecology with R. Use R! Series, Springer, New York NY, USA.X. ISBN: 978-1-4419-7975-9.

Bragazza L (2008) A climatic threshold triggers the die-off of peat mosses during an extreme heat wave. Global Change Biology 14(11): 2688-2695.

Breeuwer A, Heijmans M, Robroek BJM, Berendse F (2008) The effect of temperature on growth and competition between Sphagnum species. Oecologia 156(1): 155-167.

Bridgham SD, Updegraff K, Pastor J (1998) Carbon, nitrogen, and phosphorus mineralization in northern wetlands. Ecology 79(7): 2571-2571.

Bridgham SD, Updegraff K, Pastor J (2001) A comparison of nutrient availability indices along an ombrotrophic-minerotrophic gradient in Minnesota wetlands. Soil Science Society of America Journal 65(1): 259-269.

Carlson ML, Flagstad LA, Gillet F, Mitchell EAD (2010) Community development along a proglacial chronosequence: are above-ground and below-ground community structure controlled more by biotic than abiotic factors? Journal of Ecology 98(5): 1084-1095.

Clymo RS, Hayward PM (1982) The ecology of Sphagnum. In: Bryophyte Ecology. AEJ Smith. Chapman \& Hall, New York. pp. 229-289.

Criquet S, Farnet AM, Tagger S, Le Petit J (2000) Annual variations of phenoloxidase activities in an evergreen oak litter: influence of certain biotic and abiotic factors. Soil Biology \& Biochemistry 32(11-12): 1505-1513. 
Criquet S, Tagger S, Vogt G, Iacazio G, Le Petit J (1999) Laccase activity of forest litter. Soil Biology \& Biochemistry 31(9): 1239-1244.

Dabros A, Fyles JW (2010) Effects of open-top chambers and substrate type on biogeochemical processes at disturbed boreal forest sites in northwestern Quebec. Plant and Soil 327(1-2): 465-479.

Dabros A, Fyles JW, Strachan IB (2010) Effects of open-top chambers on physical properties of air and soil at post-disturbance sites in northwestern Quebec. Plant and Soil 333(12): 203-218.

Delarue F, Laggoun-Défarge F, Disnar JR, Lottier N, Gogo S (2011) Organic matter sources and decay assessment in a Sphagnum-dominated peatland (Le Forbonnet, Jura Mountains, France): impact of moisture conditions. Biogeochemistry (in press).

Dorrepaal E, Aerts R, Cornelissen JHC, Callaghan TV, van Logtestijn RSP (2004) Summer warming and increased winter snow cover affect Sphagnum fuscum growth, structure and production in a sub-arctic bog. Global Change Biology 10(1): 93-104.

Ellis T, Hill PW, Fenner N, Williams GG, Godbold D, Freeman C (2009) The interactive effects of elevated carbon dioxide and water table draw-down on carbon cycling in a Welsh ombrotrophic bog. Ecological Engineering 35(6): 978-986.

Escofier B, Pages J (1994) Multiple factor-analysis (afmult package). Computational Statistics \& Data Analysis 18(1): 121-140.

Fenner N, Freeman C, Reynolds B (2005) Hydrological effects on the diversity of phenolic degrading bacteria in a peatland: implications for carbon cycling. Soil Biology \& Biochemistry 37(7): 1277-1287.

Fenner N, Ostle NJ, McNamara N, Sparks T, Harmens H, Reynolds B, Freeman C (2007) Elevated $\mathrm{CO} 2$ effects on peatland plant community carbon dynamics and DOC production. Ecosystems 10(4): 635-647.

Freeman C, Evans CD, Monteith DT, Reynolds B, Fenner N (2001a) Export of organic carbon from peat soils. Nature 412(6849): 785-785.

Freeman C, Lock MA, Reynolds $\mathrm{B}$ (1993) Fluxes of $\mathrm{CO}_{2}, \mathrm{CH}_{4}$ and $\mathrm{N}_{2} \mathrm{O}$ from a welsh peatland following simulation of water-table draw-down - potential feedback to climatic-change. Biogeochemistry 19(1): 51-60.

Freeman C, Ostle N, Kang H (2001b) An enzymic 'latch' on a global carbon store - A shortage of oxygen locks up carbon in peatlands by restraining a single enzyme. Nature 409(6817): 149-149.

Freeman C, Ostle NJ, Fenner N, Kang H (2004) A regulatory role for phenol oxidase during decomposition in peatlands. Soil Biology \& Biochemistry 36(10): 1663-1667.

Gillet F, Peter M, Ayer F, Butler R, Egli S (2010) Long-term dynamics of aboveground fungal communities in a subalpine Norway spruce forest under elevated nitrogen input. Oecologia 164(2): 499-510.

Gorham E (1991) Northern peatlands: role in the carbon cycle and probable responses to climatic warming. Ecological Applications 1(2): 181-195.

Herms DA, Mattson WJ (1992) The dilemma of plants - to grow or defend. Quarterly Review of Biology 67(3): 283-335.

Husson F, Josse J, Lê S, Mazet J 2009. FactoMineR: Factor Analysis and Data Mining with 
R.In: R package, version 1.12 http://CRAN.R-project.org/package=FactoMineR.

IPCC (2007) Solomon S, Qin D, Manning M, Chen Z, Marquis M, Averyt KB, Tignor M, Miller HL, eds. Climate change 2007: the Physical Science Basis. Contribution of Working Group I to the Fourth Assessment Report of the Intergovernmental Panel on Climate Change. Cambridge University Press, Cambridge, UK and New York, NY, USA, p 996

Jassey VEJ, Chiapusio G, Mitchell EAD, Binet P, Toussaint ML, Gilbert D (2011a) Finescale horizontal and vertical micro-distribution patterns of testate amoebae along a narrow fen/bog gradient. Microbial Ecology 61(2) 374-385.

Jassey VEJ, Gilbert D, Binet P, Toussaint M-L, Chiapusio G (2011b) Effect of a temperature gradient on Sphagnum fallax and its associated microbial communities: a study under controlled conditions. Canadian Journal of Microbiology 57(3) 226-235.

Josse J, Pages J, Husson F (2008) Testing the significance of the RV coefficient. Computational Statistics \& Data Analysis 53(1): 82-91.

Laiho R (2006) Decomposition in peatlands: Reconciling seemingly contrasting results on the impacts of lowered water levels. Soil Biology \& Biochemistry 38(8): 2011-2024.

Marion GM, Henry GHR, Freckman DW, Johnstone J, Jones G, Jones MH, Levesque E, Molau U, Molgaard P, Parsons AN, Svoboda J, Virginia RA (1997) Open-top designs for manipulating field temperature in high-latitude ecosystems. Global Change Biology 3: 20-32.

Mason HS (1948) The chemistry of melanin III. Mechanism of the oxidation of dihydroxypehnylalanine by tyrosinase. Journal Of Biological Chemistry 172 83-99.

Mattson WJ, Julkunen-Tiitto R, Herms DA (2005) $\mathrm{CO}_{2}$ enrichment and carbon partitioning to phenolics: do plant responses accord better with the protein competition or the growth differentiation balance models? Oikos 111(2): 337-347.

Meehl GA, Tebaldi C (2004) More intense, more frequent, and longer lasting heat waves in the 21st century. Science 305(5686): 994-997.

Mellegard H, Stalheim T, Hormazabal V, Granum PE, Hardy SP (2009) Antibacterial activity of sphagnum acid and other phenolic compounds found in Sphagnum papillosum against food-borne bacteria. Letters in Applied Microbiology 49(1): 85-90.

Moore PD (2002) The future of cool temperate bogs. Environmental Conservation 29(1): 320.

Oksanen J, Blanchet G, Kindt R, Legendre P, O'Hara RG, Simpson GL, Solymos P, Stevens MHH, Wagner H (2010) vegan: Community Ecology Package. R package version 1.17-1. http://CRAN.R-project.org/package=vegan

Opelt K, Chobot V, Hadacek F, Schonmann S, Eberl L, Berg G (2007) Investigations of the structure and function of bacterial communities associated with Sphagnum mosses. Environmental Microbiology 9(11): 2795-2809.

Peres-Neto PR, Legendre P, Dray S, Borcard D (2006) Variation partitioning of species data matrices: Estimation and comparison of fractions. Ecology 87: 2614-2625

Pind A, Freeman C, Lock MA (1994) Enzymatic degradation of phenolic materials in peatlands-measurment of phenol oxidase activity. Plant and Soil 159(2): 227-231.

R Development Core Team (2010) R: A language and environment for statistical computing. 
R Foundation for Statistical Computing, Vienna, Austria. ISBN 3-900051-07-0, URL http://www.R-project.org.

Robert P, Escoufier Y (1976) Unifying tool for linear multivariate statistical-methods - rvcoefficient. Journal of the Royal Statistical Society Series C-Applied Statistics 25(3): 257-265.

Rydin H, Jeglum JK (2006) The Biology of peatlands. In: Oxford University Press. p 354.

Schar C, Vidale PL, Luthi D, Frei C, Haberli C, Liniger MA, Appenzeller C (2004) The role of increasing temperature variability in European summer heatwaves. Nature 427(6972): 332-336.

Sinsabaugh RL (2010) Phenol oxidase, peroxidase and organic matter dynamics of soil. Soil Biology \& Biochemistry 42(3): 391-404.

Sinsabaugh RL, Shah JJF (2011) Ecoenzymatic stoichiometry of recalcitrant organic matter decomposition: the growth rate hypothesis in reverse. Biogeochemistry 102(1-3): 3143.

Smith LC, MacDonald GM, Velichko AA, Beilman DW, Borisova OK, Frey KE, Kremenetski KV, Sheng Y (2004) Siberian peatlands a net carbon sink and global methane source since the early Holocene. Science 303(5656): 353-356.

Strack M (2008) Peatlands and Climate Change. In: International Peat Society, Vapaudenkatu 12, 40100 Jyväskylä, Finland. p 235.

Thormann MN (2006) Diversity and function of fungi in peatlands: A carbon cycling perspective. Canadian Journal of Soil Science 86(2): 281-293.

Thormann MN, Currah RS, Bayley SE (2001) Microfungi isolated from Sphagnum fuscum from a southern boreal bog in Alberta, Canada. Bryologist 104(4): 548-559.

Thormann MN, Currah RS, Bayley SE (2002) The relative ability of fungi from Sphagnum fuscum to decompose selected carbon substrates. Canadian Journal of Microbiology 48(3): 204-211.

Thormann MN, Currah RS, Bayley SE (2004) Patterns of distribution of microfungi in decomposing bog and fen plants. Canadian Journal of Botany 82(5): 710-720.

Toberman H, Freeman C, Evans C, Fenner N, Artz RRE (2008) Summer drought decreases soil fungal diversity and associated phenol oxidase activity in upland Calluna heathland soil. Fems Microbiology Ecology 66(2): 426-436.

Toberman H, Laiho R, Evans CD, Artz RRE, Fenner N, Strakova P, Freeman C (2010) Longterm drainage for forestry inhibits extracellular phenol oxidase activity in Finnish boreal mire peat. European Journal of Soil Science 61(6): 950-957.

van Breemen N (1995) How Sphagnum Bogs Down Other Plants. Tree 10: 270-275.

Verhoeven JTA, Liefveld WM (1997) The ecological significance of organochemical compounds in Sphagnum. Acta Botanica Neerlandica 46(2): 117-130.

Verhoeven JTA, Toth E (1995) Decomposition of Carex and Sphagnum litter in fens - effect of litter quality and inhibition by living tissue-homogenates. Soil Biology \& Biochemistry 27(3): 271-275.

Veteli TO, Mattson WJ, Niemela P, Julkunen-Tiitto R, Kellomaki S, Kuokkanen K, Lavola A (2007) Do elevated temperature and CO2 generally have counteracting effects on phenolic phytochemistry of boreal trees? Journal of Chemical Ecology 33(2): 287- 
296.

603

604

605

606

607

608

609

610

611

612

613

614

615

616

617

618

Weltzin JF, Bridgham SD, Pastor J, Chen JQ, Harth C (2003) Potential effects of warming and drying on peatland plant community composition. Global Change Biology 9(2): 141-151.

Weltzin JF, Harth C, Bridgham SD, Pastor J, Vonderharr M (2001) Production and microtopography of bog bryophytes: response to warming and water-table manipulations. Oecologia 128(4): 557-565.

Weltzin JF, Pastor J, Harth C, Bridgham SD, Updegraff K, Chapin CT (2000) Response of bog and fen plant communities to warming and water-table manipulations. Ecology 81(12): 3464-3478.

Wetzel RG (1992) Gradient-dominated ecosystems - sources and regulatory functions of dissolved organic-matter in fresh-water ecosystems. Hydrobiologia 229: 181-198.

Wheeler BD, Proctor MCF (2000) Ecological gradients, subdivisions and terminology of north-west European mires. Journal of Ecology 88(2): 187-203.

Williams CJ, Shingara EA, Yavitt JB (2000) Phenol oxidase activity in peatlands in New York State: Response to summer drought and peat type. Wetlands 20(2): 416-421 
619 Table 1: Seasonal variations of environmental variables measured in controls and OTCs in the

620 fen and bog sampling areas in Le Forbonnet mire (French Jura). Letters indicate significant 621 seasonal variations $(P<0.05)$. Asterisks indicate significant variations between controls and 622 OTCs $(P<0.05)$.

623 Table 2: Summary of RDA on Sphagnum related biochemical variables and environmental 624 explanatory variables from Le Forbonnet mire (French Jura): fraction of variance explained 625 and significance of individual variables taken alone. Sph moisture $=$ Sphagnum moisture 626 content; clim treat $=$ climate treatment.

627 Table 3: RV-coefficients (RV) and corresponding $P$-values among the six groups of variables 628 used in the Multiple factor analysis (MFA) of the entire data set split into 6 groups of 629 variables describing Sphagnum biochemistry, environmental physical and chemical 630 conditions, climate warming treatment, seasons, depth of moss segment and bog/fen areas . 631 Significant coefficients are in bold.

632

633

634

635

636

637

638

639 
Figures:

641 Figure 1: Seasonal variations of Sphagnum moisture content in the two shoot segments (top 642 and bottom) in controls and OTCs of the fen $(a, b)$ and bog $(c, d)$ areas. Mean \pm S.E. $(n=3)$. 643 Asterisk indicates significant difference between controls and OTCs (ANOVA tests, $P<$ 644 $0.05)$.

Figure 2: Seasonal variations of bound $(a, b, c, d)$ and free $(e, f, g, h)$ phenolics in the two shoot segments (top and bottom) in controls and OTCs of the bog and fen areas. Mean \pm S.E. $(\mathrm{n}=3)$. Asterisk indicates significant difference between controls and OTCs (ANOVA tests, $P$ $<0.05)$.

Figure 3: Seasonal variations of densities of fungi producing phenoloxidases (a, b, c, d) and phenoloxidase activities (e, f, $\mathrm{g}, \mathrm{h}$ ) in the two shoot segments (top and bottom) in controls and OTCs of the bog and fen areas. Mean \pm S.E. $(n=3)$. Asterisk indicates significant difference between controls and OTCs (ANOVA tests, $P<0.05$ ).

Figure 4: Correlations between free phenolics and phenoloxidase activity for Sphagnum segments (top and bottom segments pooled) in controls and OTCs in the fen (a) and bog (b) areas.

Figure 5: Biplots of redundancy analyses (RDA) of biochemical data measured on Sphagnum mosses (free and bound phenolics, phenoloxidases and fungi-producing phenoloxidases) in segments of the bog area. Climate treatments are coded with open symbol for controls and with filled symbol for OTCs. Months are indicated next to the sample points by their number. Season effect has been removed by giving the variable months as covariable. Environmental variables are represented by vectors (arrows for quantitative or semi-quantitative variables): 

Figure 6: Multiple factor analysis (MFA) samples biplot of the entire data set split into 7 670

moisture and OTCs. Biochemical variables are given with dotted arrows: F_phen: free phenolics, B_phen: bound phenolics; Phen_oxid: phenoloxidase activity; Fungi: culturable fungi-producing phenoloxidase. Axes are significant $(P<0.05)$, except for bottom segments. Axes 3 are never significant, with less than $1 \%$ of variance). Grey ellipses represent S.E. of site scores around the centroid of each treatment level.

groups of variables describing Sphagnum biochemistry, environmental physical and chemical conditions, climate warming treatment, seasons and fen-bog areas. Biplot of axes 1 and 2 (both significant at $P=0.001$ ) is given together with the result of a hierarchical agglomerative clustering (grey lines) obtained by the Ward method on the Euclidean distance matrix between MFA site scores, showing three main groups of sampling plots (circles = spring, squares $=$ summer, triangles $=$ autumn $)$ and two sub-groups $($ white symbols $=$ controls, black symbols $=$ OTCs). Sampling areas are indicated with letters besides sampling plots (F: fen area; B: bog area). 